\title{
KEPERAGAAN DALAM MENGATASI ANAK LAMBAN MEMAHAMI PELAJARAN
}

\author{
Sambira Mambela \\ Program Studi Pendidikan Khusus \\ Universitas PGRI Adi Buana Surabaya \\ Sam.mambela@gmail.com
}

\begin{abstract}
Abstrak
Kapasitas anak dalam belajar di sekolah berbeda-beda atau bervariasi, kemampuan untuk memahami pelajaranpun berbeda antara anak yang satu dengan yang lain. Dapat dipastikan bahwa dalam suatu kelas akan ditemukan anak yang cepat, biasa, dan lambat dalam memahami pelajaran. Sering terjadi, guru memilih dan menerapkan pendekatan, metode dan strategi pembelajaran yang sama pada anak yang cepat, biasa, dan lambat memahami pelajaran, bahkan pencapaian tujuan dan kemajuan belajar hanya didasarkan pada kemampuan dan kemajuan belajar anak yang cepat memahami pelajaran. Akhirnya anak yang lambat dalam memahami pelajaran akan sulit mengimbangi kemampuan belajar anak yang cerdas dan cepat dalam belajar. Anak yang cerdas dan cepat memahami pelajaran saja yang selalu menapat nilai yang tinggi, nilai anak yang lambat memahami pelajaran selalu rendah dan bahkan di beri label bodoh. Bagaimana cara Mengatasi Anak yang lambat memahami dan atau lambat mencapai tujuan pembelajaran ? Salah satu yang dapat dilakukan guru adalah membelajarkan mereka (anak lambat belajar) dengan prinsip dan metode keperagaan, artinya dengan prinsip ini guru dalam mengajar terutama tentang hal-hal yang verbal atau abstrak guru selalu berusaha mengkonkritkan dengan peragaan-peragaan. Dengan demikian anak akan terbantu, dengan kata lain alat peraga akan membantu anak lamban belajar untuk mengatasi kesalahpahaman dan kesalahan dalam menangkap penjelasan lisan/verbal.
\end{abstract}

Kata Kunci: Anak, lambat belajar, pembelajaran, keperagaan.

\section{PENDAHULUAN}

Kapasitas anak dalam belajar di sekolah berbeda-beda atau bervariasi, kemampuan untuk memahami pelajaranpun berbeda antara anak yang satu dengan yang lain. Dapat dipastikan bahwa dalam suatu kelas akan ditemukan anak yang cepat, biasa, dan lambat dalam memahami pelajaran. Variasi kondisi kemampuan anak dalam belajar tersebut, menuntut kiat dan kreativitas guru dalam merancang dan melaksanakan pembelajaran agar semua anak dapat belajar seoptimal mungkin.

Berkaitan dengan hal ini guru harus mampu tahu, memilih dan menentukan, merancang, dan melaksanakan pembelajaran yang diindividualisasikan (menghadapi peserta didik secara klasikal namun tetap memperhatikan perbedaan individu anak). 
Sering terjadi, guru memilih dan menerapkan pendekatan, metode dan strategi pembelajaran yang sama pada anak yang cepat, biasa, dan lambat memahami pelajaran, bahkan pencapaian tujuan dan kemajuan belajar hanya didasarkan pada kemampuan dan kemajuan belajar anak yang cepat memahami pelajaran.

Akhirnya anak yang lambat dalam memahami pelajaran akan sulit mengimbangi kemampuan belajar anak yang cerdas dan cepat dalam belajar. Anak yang cerdas dan cepat memahami pelajaran saja yang selalu menapat nilai yang tinggi atau baik, nilai anak yang lambat memahami pelajaran selalu rendah dan bahkan di beri label bodoh.

Transley dan R. Gulliford (1971: 4) menjelaskan beberapa karakteristik anak lambat dalam belajar (Slow Learner) diantaranya adalah: (1) kemampuan berfikirnya agak rendah, sehingga lamban dalam memecahkan masalah-masalah yang sederhana. Hal ini menyebabkan mereka kalah bersaing dengan teman-temannya yang normal; (2) Ingatannya agak lemah dan tidak tahan lama. Mereka gampang lupa dan biasanya tidak mampu mengingat-ingat suatu peristiwa yang terjadi tiga tahun yang lewat.

Dalam proses belajar mengajar di sekolah, apa yang diterangkan oleh guru hari ini biasanya beberapa saat atau umumnya satu minggu kemudian sudah terlupakan. Lebih lagi dalam mengingat-ingat isi buku pelajaran yang telah dibaca/dipelajari sendiri. Kalau murid-murid normal dapat mengingat isi pelajaran lebih kurang 50\% setelah membaca dua kali, maka murid lambat belajar hanya mampu mengingat 25\% saja bahkan kurang dari itu.

Selain kemampuan berfikir dan mengingat lemah, anak lambat belajar juga kurang mampu berfikir abstrak, oleh karena itu, untuk meminimalisir masalah kelambanan mereka dalam memahami pelajaran guru juga dituntut mampu mengkreasi atau guru harus mempunyai kreativitas untuk mengkongkretkan setiap materi ajaran pada anak lamban belajar.

Anak lambat belajar, bukanlah anak terbelakang mental (mentally retardation), mereka akan mampu mencapai hasil belajar pada umumnya bila gurunya kreatif dan pandai memilih strategi pendekatan dan metode pembelajaran serta bimbingan yang tepat.

Kreativitas guru dalam mengatasi masalah anak lamban belajar penting karena selain mengajar, guru juga bertugas sebagai stimulator, motivator, kontruktor, mediator, dan dituntut mampu memposisikan diri dalam berbagai kondisi pendidikan dan pembelajaran peserta didiknya.

Sering dan banyak sekali guru yang bertanya "Bagaimana cara Mengatasi Anak yang lambat memahami dan mencapai tujuan 
pembelajaran ?" para guru tentu sudah mencoba berbagai cara mengatasi, namun hasilnya belum memuaskan. Oleh karena itu dalam artikel ini kita akan membahas salah satu cara mengatasi yaitu tentang "Keperagaan Dalam Mengatasi Anak Lamban Memahami Pelajaran."

\section{PEMBAHASAN}

Keperagaan sering disebut juga dengan istilah: Audio Visual Aids, teaching aids, yang dapat diartikan alat bantu. Ini berguna untuk memperjelas pengajaran yang disampaikan guru kepada murid. Sehingga anak akan lebih jelas menangkap penjelasan guru setelah diperhatikan/diperdengarkan sesuatu kepada anak. Pemakaian alat peraga dalam proses belajar mengajar, di antara berbagai tujuan yang hendak dicapai adalah untuk menghindari timbulnya verbalisme. Ini bukan berarti guru tidak boleh mengajar dengan menggunakan bahasa atau kata-kata.

Bahasa dan kata-kata akan memberi arti kepada pengalaman sehingga kita dapat menguasai dunia sekitar. Tanpa disertai peragaan yang konkrit anak lambat belajar akan lebih sulit menerima pelajaran melalui penjelasan kalimat atau kata-kata saja. Kesulitan-kesulitan yang dihadapi anak lambat belajar disebabkan, anak lambat belajar sulit/terbatas kemampuannya dalam mengabstraksi sering sulit memahami sesuatu yang diberikan melalui kata-kata saja. Ini harus dibantu dengan dikonkretkan.

Dengan kata lain alat peraga membantu anak lamban belajar untuk mengatasi kesalahpahaman menangkap penjelasan lisan/verbal. Di sini mungkin akan timbul pertanyaan, apakah metode verbal tidak dapat dipergunakan dalam mengajar anak lamban belajar ? Dan apakah metode keperagaan menjamin anak lamban belajar menjadi lancar dalam menerima pelajaran?

$$
\text { Marilah kita tinjau }
$$

bagaimanakah kemungkinankemungkinan dan kemampuan yang dimiliki, keunggulan dan kelemahan masing-masing. Sejauh mana kelemahan bisa dikurangi, sebenarnya tergantung juga dari pemakaian metode dan pendekatan itu sendiri, yaitu guru.

Prinsip dan metode peragaan memang banyak membantu anak lamban belajar, namun metode verbal pun dalam hal ini memiliki keunggulan dalam penyampaian materi secara lisan untuk memperjelas pengertianpengertian. Dari mengenal pengertian sederhana melalui peragaan, selanjutnya akan dikembangkan melalui metode verbal.

Verbalisme akan dapat diatasi asalkan guru bertitik tolak dari hal dan dasar-dasar: (a) Pengertian/pengalaman yang telah dimiliki anak; (b)Tingkat kematangan anak untuk mengabstraksi; (c) Disertai dengan usaha memperoleh 
vicarious experience (pengalaman yang mengganti).

\section{Alat peraga dengan berbagai jenis}

Terdapat berbagai jenis alat peraga, namun guru harus mengetahui dan memahami juga bagaimana alat peraga yang baik, maksudnya yang dapat dan tepat dipakai dalam menyampaikan pelajaran. Adapun alat peraga yang baik adalah: (a). Sesuai dengan tujuan; (b) Sederhana; (c) Langsung menunjukkan isi dan arti; (d) Bentuknya jelas dan benar (sesuai); (e) Tidak membingungkan; (f) Mudah diingat; (g) Menarik bagi anak; (h) Harganya murah, (i) Tidak membahayakan; dan (j) Praktis dalam penggunaannya.

Adapun nilai dari peragaan yang diharapkan setelah persyaratanpersyaratan pemilihan alat peraga terpenuhi diharapkan akan diperoleh variasi dalam cara-cara mengajar, memberikan lebih banyak realitas dalam mengajar sehingga lebih berwujud dan lebih terarah untuk mencapai tujuan pelajaran.

Alat-alat peraga sebagai alat pembantu dalam mengajar agar efektif dalam garis besarnya memiliki kaidah sebagai berikut: (a) Menambah kegiatan belajar mengajar murid; (b) Menghemat waktu belajar; (c) Agar hasil belajar lebih mantap; (d) Membantu anak yang ketinggalan dalam belajar; (e)
Membangkitkan motivasi dan aktivitas pada anak.

\section{Klasifikasi Alat Peraga}

Secara garis besar alat peraga dapat diklasifikasikan kedalam 3 kelompok, yaitu: (a) Kelompok mengamati yang, meliputi: Demonstrasi, darmawisata, pameran, Gambar hidup, dan Rekaman (radio gambar mati); (b) Kelompok berbuat, yakni: pengalaman langsung, pengalaman yang diatur, dan drama tisasi; (c) Kelompok menggunakan lambang terdiri dari: lambang visual, lambang verbal.

Hal tersebut sesuai dengan pendapat Edgar Dale bahwa kita dapat belajar dengan: mengalaminya secara, langsung: dengan melakukannya atau berbuat; dengan mengamati orang lain melakukannya; dan dengan membaca.

Pengalaman yang nyata dibutuhkan untuk setiap tahapan di atasnya. Namun penting diingat, bahwa pencapaian pengalaman yang lebih abstrak akan terhambat bila pengalaman langsung terlalu banyak. Jangan membandingkan dengan abstrak. Yang abstrak itu belum pasti lebih sukar dari yang nyata/ kongkrit. Edgar Dale Dalam Sumadi Suryabrata (1984) membuat tingkatan-tingkatan yang dimaksud diatas dalam kerucut di bawah ini: 


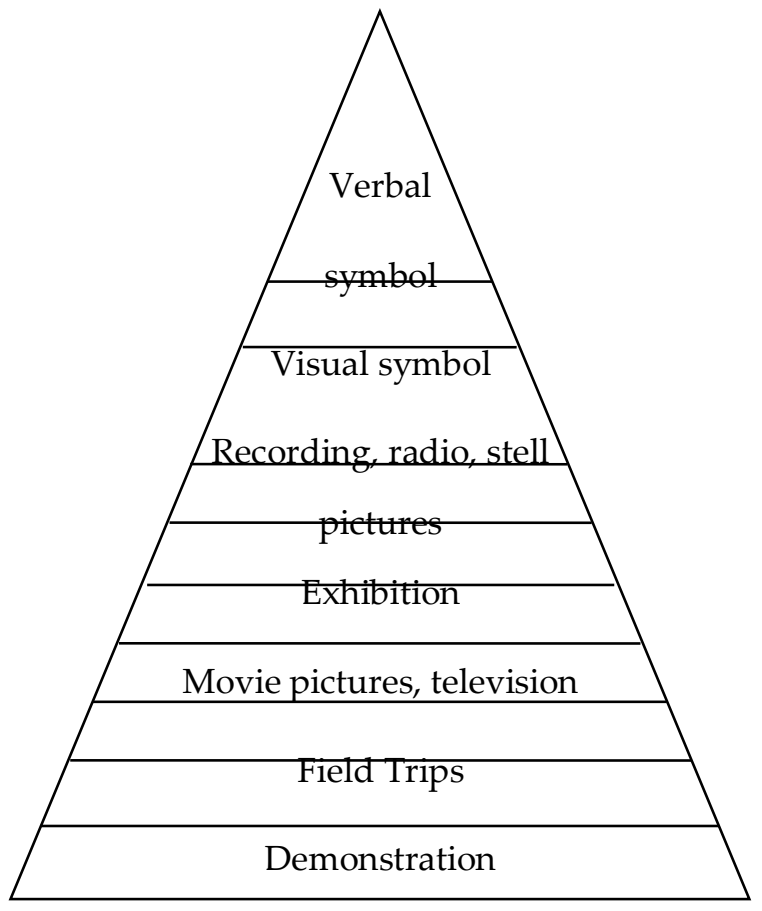

Maksud dan makna isi bagan dalam bentuk kerucut di atas, adalah :

1. Mengalami/pengalaman langsung.

Dalam hal ini anak-anak diminta melakukan, mengalami, dan berbuat sendiri serta mengolah, merenungkan hal yang dilakukannya dan juga mengekspresikannya dalam lambanglambang lain.

\section{Pengalaman yang dibikin.}

Apabila realita terlalu rumit, terlampau luas/besar, terlalu kecil atau tidak tersedia maka hal nyata itu dapat buat dalam bentuk yang lebih jelas dan memudahkan untuk dipahami.

\section{Dramatisasi.}

Dalam hal ini, penyajian melalui: sandiwara, sosiodrama, pantomimi, tableau, sandiwara boneka.

\section{Demonstrasi.}

Dalam demonstrasi harus diperhatikan bagaimana sesuatu harus dilakukan. Pada umumnya dilakukan dengan menggunakan alat-alat bantu (papan flanel, papan tulis, dan sebagainya).

5. Karyawisata.

Untuk mengatasi keterbatasan pengalaman langsung, dilakukan darmawisata.

\section{Pameran}

Pameran akan memotivasi anak menjadi aktif dan timbul latihan kerjasama antara teman satu dengan lainnya. Yang dipamerkan adalah alat/benda-benda yang realistik, bendabenda tersebut diatur dengan maksud untuk menjadikan suatu idea.

7. Gambar hidup/ televisi

Televisi/gambar hidup merupakan alat yang efektif, pada televisi ini dapat dilihat dan diamati. Peristiwa yang terjadi pada saat itu juga, dan suatu program yang telah disiapkan lebih dahulu berupa film, demonstrasi, sandiwara ada pula bernuansa pendidikan.

8. Film sebagai alat peragaan

Film merupakan alat peraga yang mempunyai banyak sisi positif dan efisien, karena: banyak hal-hal yang dapat dipelajari dari film, film dapat mengajarkan sesuatu dalam waktu yang lebih singkat, film lebih berhasil bila dihubungkan dengan alat-alat peraga lain, Film memberi dorongan pada aktivitas-aktivitas lain.

9. Gambar bagi alat peraga

Gambar masuk lingkup alat peraga yang bernuansa abstrak, namun 
gambar masih dapat "menangkap" gerak sehingga mendekati pada kenyataan, sedang peta dan diagram lebih bersifat abstrak. Dengan gambar anak didik yang lamban dapat melihat dan latihan menafsirkan gambar tersebut.

10. Lambang kata

Lambang kata merupakan pengganti hal-hal yang nyata. Lambang kata tidak punya persamaan nyata dengan idea atau benda-benda yang dinyatakan. Kata-kata merupakan keadaan abstrak yang mutlak, sama sekali tidak ada kesamaan dengan benda yang dilambangkan.

\section{Alat Peraga Yang Sesuai Bagi Anak Lambat Berlajar}

Berdasarkan hirarkis alat peraga menurut Edgar Dale yang dipaparkan di atas, sebagian besar dapat diterapkan kepada anak lamban memahami pelajaran. Namun manfaat pemakaian dan materi serta material yang digunakan wajib mengacu pada kebutuhan anak lamban menerima pelajaran. Berikut ini akan kita dikemukakan penggunaan alat peraga yang sesuai dengan kepentingan mengajar anak-anak lamban belajar.

a. Pengalaman langsung

Peraga ini diberikan kepada anak lamban belajar, dengan mengalami langsung anak akan menemukan masalah-masalah atau hal nyata yang kemudian akan dibawa ke kelas untuk dilaporkan kepada guru. Selanjutnya masalah tersebut akan dijadikan bahan/dasar atau suatu topik pembicaraan oleh guru dalam kaitan dengan bidang ajaran yang diajarkan. Dalam hal ini guru dituntut siap dan kreatif dalam menghadapi masalah yang dibawa oleh anak.

b. Dramatisasi :

Termasuk dari banyak media bagi anak untuk menghubungkan pengalaman/pengertian, sesuatu masalah ke dalam bentuk perbuatan nyata. Hal ini sekaligus untuk menilai, seberapa dan sejauh manakah kemampuan anak lamban belajar memahami penjelasan guru, serta menilai kemampuan komunikasi lisan anak.

\section{c. Demonstrasi :}

Anak lamban belajar umumnya kurang mampu dan mengalami kesulitan dalam meng abstraksikan sesuatu untuk memperjelas dan memudahkan dalam mengambil/sampai pada pemahaman atau pengertian, dalam hal itu guru perlu mendemonstrasikan.

d. Karyawisata atau darmawisata

Karyawisata sangat bermanfaat bagi anak lamban, dilaksanakan mulai di sekitar sekolah, Selain anak lamban dapat diajak mengenal sesuatu yang konkrit sehingga membantu kelancaran memahami materi pelajaran, anak lamban juga memperoleh berbagai baru yang. Karyawisata ini akan menunjang 
anak lamban dalam belajar IPS maupun IPA.

Banyak hal yang akan membingungkan anak lamban karena terlalu sulit dimengerti. Misalnya kerjasama, upacara pemujaan, kantor berita, butik, bursa dan sebagainya.

Melalui pengenalan langsung anak lamban akan menjadi percaya dan yakin pada penjelasan guru. Kesalahan daldm memahami penjelasan, sering terjadi pada anak karena anak kurang mampu menangkap penjelasan guru.

e. Televisi/gambar hidup :

Banyak hal yang dapat diambil anak lamban belajar dari menonton/melihat televisi atau gambar hidup. Anak lamban dapat mengasah diri untuk mengembangkan kemampuan membaca hal dan melatih pendengaran. Dalam kaitan dengan seni (seni tari/seni suara), anak dapat mengidentifikasi irama lagu dengan jalan mengamati pola gerak dan mimik yang diamati.

f. Alat peraga film :

Sebagaimana halnya media gambar hidup/televisi, film akan memberi manfaat pengamatan pada anak lamban belajar, akan mendapat kesan yang lebih jelas, yakni membantu penyampaian pelajaran dengan alat peraga lain. Akan lebih baik lagi jika anak diberi peran dalam film tersebut sehingga anak akan semakin paham dan yakin terhadap kemampuan dirinya. g. Gambar sebagai alat peraga

Gambar merupakan alat peraga yang praktis dan efisien. Semua aktivitas belajar mengajar sangat perlu untuk diwujudkan dalam bentuk gambar. Bagi anak tulisan akan ditangkap sebagai gambar, yang akan diidentifikasikan dengan gambar benda ataupun bendanya sendiri.

Lambang kata :

Sebagai persiapan di dalam media komunikasi sosial anak harus mampu berbicara atau berbahasa lisan. Mengenal dan memahami lambang kata, adalah mengalihkan kebiasaan memahami secara kongkrit. Dikatakan demikian karena tidak setiap saat penyampaian dilakukan melalui peragaan (konkrit). Agar anak dapat menggunakan lambang kata dengan baik, dibutuhkan pelatihan.

i. Alat peraga auditif.

Alat peraga auditif adalah alat peraga yang mengandung unsur bunyi. Ini perlu digunakan untuk melatih anak lamban untuk memahami melalui pendengarannya.

\section{SIMPULAN}

Anak lambat belajar (slow learner) ditandai dengan: 1) kondisi kemampuan berfikir agak rendah; sehingga lamban dalam memecahkan masalah-masalah yang sederhana. Sehingga kalah bersaing dengan temanteman sebayanya yang normal; 2) gampang lupa karena kondisi 
ingatannya lemah, biasanya ia kurang bahkan tidak mampu mengingat-ingat peristiwa yang terjadi/dialami tiga tahun yang lewat. Sehingga dalam proses belajar mengajar di sekolah, apa yang diterangkan oleh guru hari ini biasanya beberapa saat atau umumnya satu minggu kemudian sudah terlu] hanya dapat mengingat $25 \%$ dari isi buku pelajaran pelajaran yang dibaca/dipelajari bahkan kurang dari itu.

Anak lambat belajar bukanlah anak terbelakang mental (Mentally Retardation yang sudah tidak dapat mencai hasil belajar anak-anak pada umumnya). Dengan prinsi/strategi/metode dan pendekatan pembelajaran yang sesuai Anak lambat belajar dapat mencapai hasil/prestasi belajar anak-anak pada umumnya.

Salah satu cara mengatasi masalah/kesulitan belajar anak lambat belajar, adalah membelajarkan mereka dengan prinsi dan metode keperagaan, yakni dalam membelajarkan mereka guru harus selalu berusaha meragakan atau mengkonkrit kan bahan terutama bahan-bahan ajaran yang bersifat abstrak/verbal.

Peragaan dapat dalakukan oleh guru dengan cara/teknik: Pengalaman lang sung ,Pengalaman yang diatur , Dramatisasi, Demonstrasi Darmawisata, Pameran, Gambar hidup, Rekaman, radio, gambar mati, Lambang visual, Lambang verbal.
Dengan peragaan-peragaan tersebut anak dapat belajar dengan: 1) Mengalaminya secara langsung, dengan melakukannya atau berbuat; 2) Mengamati orang lain melakukannya; dan 3) Membaca.

\section{DAFTAR PUSTAKA}

Depdiknas. 2007. Pedoman Khusus Penyelenggaraan Pendidikan Inklusif (Manajemen Sekolah Penyelenggara Pendidikan Inklusif). Jakarta: Departemen Pendidikan Nasional Direktorat Jenderal Manajemen Pendidikan Dasar dan Sekolah Menengah Direktorat Pembinaan Sekolah Luar Biasa.

Hopkins, Bill. (2008). The Child Who is a Slow Learner. Teachers Resource Manual. Cortland: State University of New York.

J. David Smith. 2006. Inklusi, Sekolah Ramah Untuk Semua. Penerjemah; Denis, Ny. Enrica. Nuansa. Jakarta.

Krishnakumar, P. et. al. 2006. Effectiveness of Individualized Education Program for Slow Learners. Indian Journal of Pediatrics Volume 73 February 2006.Hlm. 135-137.

Norris G. Haring, Exceptio nal Children and Youth, An Introduction to Special Education, Charles E. Merril Publishing Company. 
Purwatiningtyas, Maylina. 2014. Strategi

Pembelajaran Anak (slow leaner) di Sekolah Inklusi;

Reddy,G. Lokanadha, R. Ramar, dan Kusuma. 2006. Slow Leaners: Their Psycholoy and Instruction. New Delhi: Discovery Publishing House.

Sumadi HS. Ortodidaktik. Departemen Pendidikan dan Kebudayaan.

Sutratinah Tirtonegoro. Anak Supernormal dan Program Pendidikannya. Yogyakarta: Bumi Aksara. Cetakan kedua 2001.

Wena, Made. 2009. Strategi Pembelajaran Inovatif Kontenmporer. Jakarta: Bumi Aksara. 